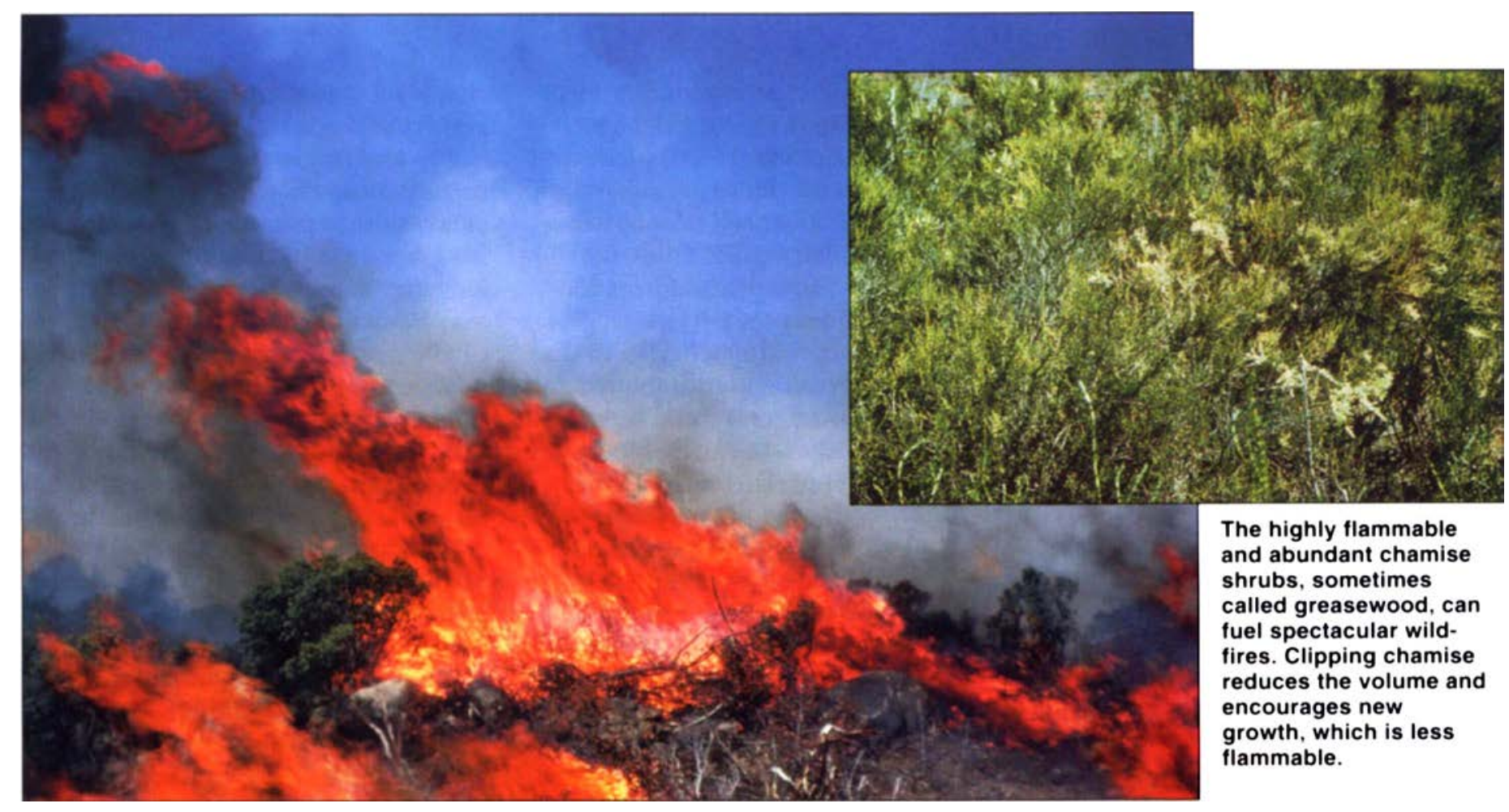

\title{
Clipping chamise reduces brush fire hazard
}

\author{
Theodore E. Adams $\square$ Peter B. Sands
}

\begin{abstract}
Wildfire is a particular concern where housing and business development encroaches on highly flammable brushlands. In these areas, it may be risky to use prescribed fire to control biomass and reduce the fuel for a fire. Chamise chaparral, the most common of the brush types, was clipped to study how biomass removal affects flammability and fire hazard. The results suggest that infrequent clipping of chamise to a height of 12 inches may adequately reduce fuel volume and encourage new growth high in moisture, which lowers the flammability of vegetation.
\end{abstract}

Wildland fires in California are annual events. Vegetation, climate and topography in the state combine to generate some of the most spectacular fires found anywhere in the world. Fire hazards are growing in severity and the size of major fires is increasing as wildland fuels accumulate (Lemp 1998). The risk of fire and human exposure is aggravated by a growing population that moves ever deeper into wildland areas (Lemp 1998). The need for institutional change to address the wildland fire problem is now recognized, but the enormity of the task is daunting; both natural and social systems must be considered.

Vegetation management is a major need, and several techniques are available to accomplish this objective. Because much of the vegetation in California is adapted to and dependent on fire for maintenance, prescribed fire to achieve ecosystem management objectives is a natural choice (Parfit 1996). However, there is continuing growth of residential communities at the urban/wildlands interface and growing development throughout many wildland areas. This makes use of fire as a management tool difficult in many situations (Lemp 1998). And fear of es- caped fire - and the damages and litigation that can result - discourage resource managers (Greenlee and Sapsis 1996).

Several ways to manage vegetation are available. One of these is the physical removal or reduction of vegetation available for burning, either by hand or mechanically. Reduction lowers the fire hazard and makes fire control an easier task. The reduction or removal of vegetation around homes and other structures in the wildlands is often the most practical technique for creating the defensible space needed by firefighters. In its report, the Governor's Task Force on Chaparral Fire and Flood Risk Management recommended the evaluation of alternative vegetation management strategies (California Resources Agency 1981).

In the study presented here, we examined the effects of aboveground plant biomass removal on the performance of chamise (Adenostoma fasciculatum). Chamise is the most 


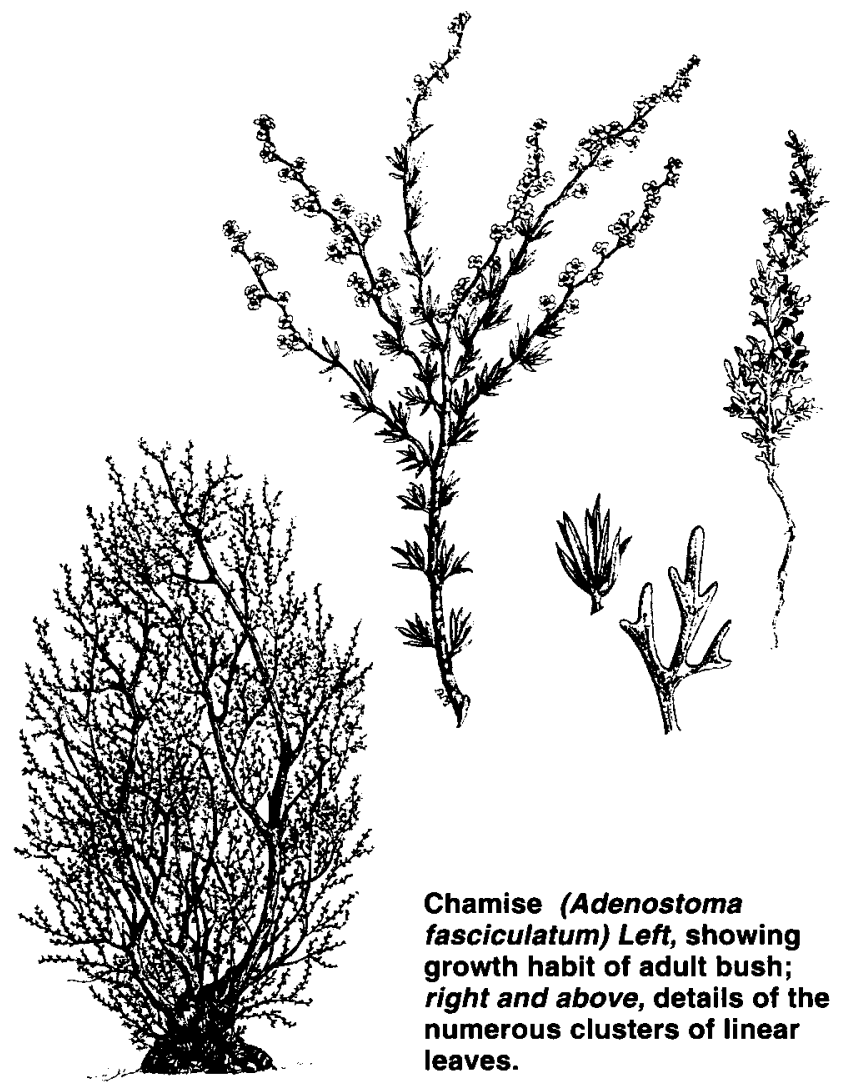

years prior to initiation of the study. Stand density was about 5,200 plants / acre with an average height of 2 feet and a canopy cover of $70 \%$ to $75 \%$.

Based on information presented by Green (1981), approximately $75 \%$ of the brush volume (about 5 tons / acre) could be considered as available fuel in a fire. This fuel volume would burn with low intensity except under extreme fire conditions temperature over $80^{\circ} \mathrm{F}$, relative humidity less than $30 \%$ and wind speed over $20 \mathrm{mph}$ (Green 1981).

The stand, surrounded by a deer-proof fence, was located on a $30 \%$ west- facing slope at an elevation of 2,500 feet where annual precipitation is 46 inches. It was growing on a com-

common and widely distributed shrub species in California's chaparral shrublands (Hanes 1977). To simulate mechanical mowing, we clipped chamise by hand each year for 5 years and measured the results annually to assess the effectiveness of the treatment as a growth control measure and the treatment's influence on the moisture content of the shrub, which affects flammability.

Preparation of this article was delayed more than 10 years as other natural resource studies were considered, at the time, to have a higher priority. However, the alarming increase in catastrophic wildfires led to the creation of the statewide California Fire Safe Council in 1993 and the subsequent and continuing creation of county Fire Safe Councils. To support the development of fire-safe communities, we have summarized the information in our study.

\section{Study site at Hopland}

Our study site was located at the UC Hopland Research and Extension Center in Mendocino County, south of Ukiah. The nearly pure stand of chamise we used had been burned 5 plex of soils (Maymen-Etsel-Snook complex) in which the Maymen series, with the greatest effective rooting depth (10 to 20 inches), dominates. Soils of the Maymen series are loamy, mixed, mesic Dystic Lithic Xerochrepts.

During the study, precipitation was above the expected in four of five growing seasons (1981-82 through 1983-84, and 1985-86). In these seasons, the amount above expected was $31 \%$ below expected. During the wettest part of the season, January to March, precipitation ranged from $86 \%$ more than expected to $61 \%$ less, with no apparent correlation to the seasonal totals.

\section{Chamise characteristics}

In chaparral, the most extensive vegetative type in the state, chamise often occurs in nearly pure stands called chamise chaparral (Hanes 1977). Because of its abundance and distribution, chamise probably produces more volume of growth than any other California shrub (Sampson and Jespersen 1963).

Chaparral grows on coarse, rocky soils of low fertility, and chamise ranged from $13 \%$ to $73 \%$. In $1984-85$, it chaparral is associated with the most xeric sites, hot south- and west-facing slopes and ridges (Hanes 1977). Moisture stress on chaparral sites is heightened for most plants by California's Mediterranean-type climate with its long, dry summers. Although soils may be shallow, the underlying rocks can be deeply fractured, and this permits deep penetration of shrub roots (Biswell 1974).

The resinous leaves of chamise are short and needlelike, an adaptation to drought, and over half the branches and stems may be less than $1 / 2$ inch in diameter (Biswell 1974). These characteristics produce a high surface-tovolume ratio and make the plant highly flammable. Because of the resinous nature of the shrub and its flammability, chamise is sometimes called greasewood.

Chamise can recover rapidly after a fire, but chamise chaparral usually recovers more slowly than other chaparral types because of the severe sites it occupies. Sprouts are produced from root-crown burls, and seedlings develop from seed scarified by the fire. Chamise is ready to burn again when dead growth begins to appear, and this can be as soon as 15 to 20 years after fire (Biswell 1974). As Biswell notes, the shrub's features generate an interaction: recurring fires maintain the health and stability of chamise, and burning of chaparral depends on chamise for the fuel needed to carry fire that impacts chamise and other fire-adapted plant species, mostly shrubs.

\section{Clipping treatments}

For 5 successive years, beginning in 1981, chamise in replicated, 15-squarefoot plots in each of four blocks was clipped annually in May to reduce growth and control it through the elimination of apical dominance. Clipping heights were 6 inches and 12 inches. Plots for each of the five harvests were randomly designated at the beginning of the study. Residues from the first and subsequent annual clippings were left where they fell. New growth at the time of clipping was approximately 3 inches long. Experiments conducted by Jones and Laude 
(1960) and Laude and others (1961) indicate that chamise is physiologically "weak" in spring when new growth equals 3 inches, a time of rapid rootstarch depletion and increasing twig moisture. Cutting at this time reduced regrowth the following year.

In five successive winters, beginning in 1982-83, one set of plots (including unclipped controls) in each block was sacrificed and cut to ground level, and green weights of the aboveground biomass were recorded. Before harvest, we remeasured canopy density. Clipped plots scheduled for harvest were not cut in May preceding the winter of harvest; shrub regrowth in these plots was 18 to 20 months old at harvest and reflected effects of the preceding clippings. We used a variety of manual and power-operated hand tools in the clipping and harvesting processes. Plants in plots sacrificed each year sprouted and regrew in subsequent years.

In clipped plots, production was divided into regrowth above the clipped height and growth below. Production in unclipped control plots was divided into comparable segments. All cut material was air-dried and reweighed, and the moisture content, expressed as a percentage of air-dry weight, was calculated. (Our measurements of moisture content underestimated fuel moisture used in prediction of fire behavior, which is based on oven-dry material.)

We evaluated the data by analysis of variance to detect differences among treatments and the control and among years. Significant effects were separated by Fisher's protected least significant difference (LSD). Significant differences are reported at the $95 \%$ level of confidence ( $\left.\begin{array}{ll}P & 0.05\end{array}\right)$. When necessary for the analysis, raw data were transformed to maintain the homogeneity of variances. The results presented are treatment averages for the original measurements.

\section{Effects of clipping}

Over 5 years, the average annual production of biomass below 6 inches was not different between the two clipping treatments or between treatments and the control. Below 12 inches, production during this period was not different between the control and the 12-inch clipping treatment. In addition, no significant trends were measured over the years. Average production of the two segments was, respectively, 3,200 pounds per acre and 5,800 pounds per acre.

Loss of terminal bud suppression did not significantly influence the production of new growth below the clipped height. In an earlier study in San Diego County, 3- to 4-year-old chamise clipped to a height of 12 inches, either once or annually for 4 successive years, produced significantly more new growth below the clipped height compared to production below this height in unclipped plots (Adams and Graves 1983). In the study reported here, lateral bud development was concentrated near the points of biomass removal; nearly all new growth was harvested as regrowth above the clipped heights.

The average 5-year production above clipped height in the two clipping treatments was different; in the 6-inch treatment, it was $70 \%$ greater than in the 12-inch treatment (table 1). Above 6 inches in the unclipped control, average 5-year production was 10 times greater than above clipped height in the 6-inch treatment; and above 12 inches, it was 12 times greater than above clipped height in the 12-inch treatment. No significant trends over years were detected for any measurement.

In the unclipped control, the 5-year average of total biomass harvested was 2 to 3 times greater than in the clipped treatments, and this production in the 12-inch treatment was 1.4 times greater than in the 6-inch treatment (table 1). In the 6-and 12-inch clipping treatments, the average annual regrowth above clipped heights represented, respectively, about $25 \%$ and $10 \%$ of the average total aboveground biomass. Above 6 and 12 inches in the unclipped control, production was, respectively, about $80 \%$ and $55 \%$ of total aboveground biomass. Again, there were no significant trends over years.

The accumulation of residues from the initial clipping and subsequent an- nual clippings was not different for the two clipping treatments in any harvest; but over 5 years, the average declined significantly, from about 9,000 pounds per acre in 1982 to 3,600 pounds per acre in 1986. The regression equation for decline was $Y=$ $10,015-1,343 X\left(r^{2}=0.76\right)$. At harvest each year, the average moisture content of residues was about $27 \%$.

When harvested, average moisture content was not different for any segment of the unclipped control, for the three standing crop segments below clipping heights in the two clipped treatments, or among the latter and the three of the control (table 2). The average was about $50 \%$. However, moisture content of regrowth in the clipping treatments was over $45 \%$ greater than in any segment of the control. Moisture content did not show a trend over years.

We found no differences in the number of plants per acre among treatments and the control or over years. Stand density throughout re-

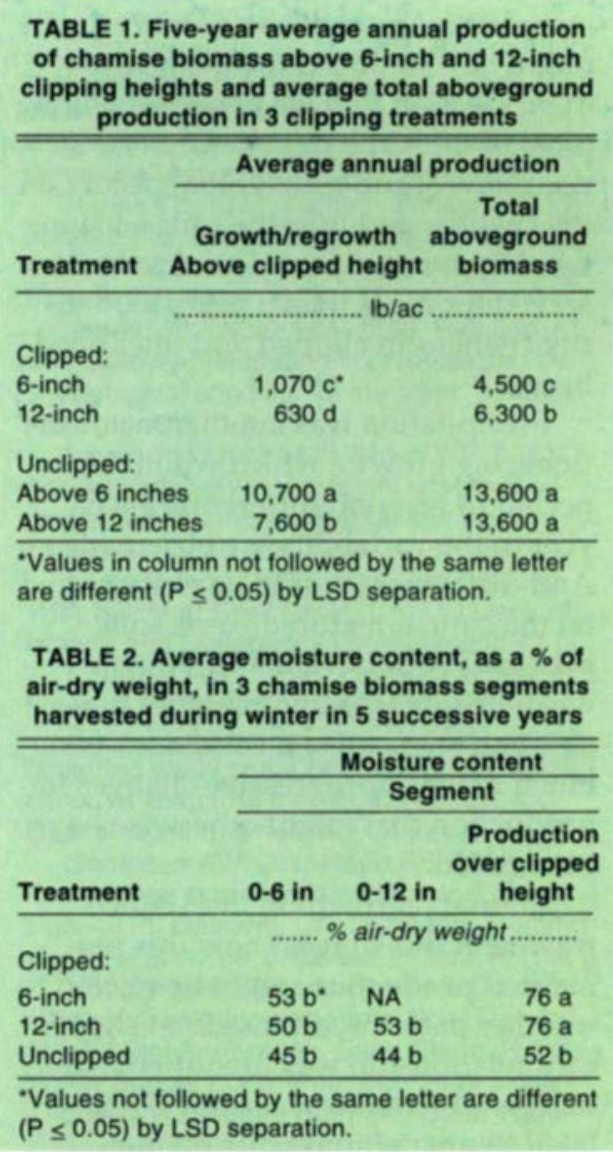


mained the same as when the study was initiated.

Average annual canopy cover in the control was the same at the end of the study as at the beginning. However, it was greater than that in the 12-inch treatment, which was greater than in the 6-inch treatment. Values were, respectively, $74 \%, 30 \%$ and $21 \%$, and each was different from the others. No differences in canopy cover among years were observed.

\section{The factor of time}

Among the data collected, only that for residue showed a significant change over years, a decline resulting from progressive decay of the biomass deposited in the initial clipping, and plant material falling to the soil surface in subsequent annual clippings. Decomposition might have been accelerated if clipped material had been more finely divided, as would occur when brush is mechanically mowed.

Several factors contributed to the failure to identify changes in production over time. Variability in the soils undoubtedly affected rates of plant growth. Larger plots would each have included more of this variability and might have reduced the inconsistency in production that we observed among plots of the same treatment. In addition, slow shrub growth that occurs on the shallow and infertile soils encountered in our study may need to be observed for more than 5 years to identify changes in clipped and unclipped brush.

Precipitation was another factor influencing growth, which would be expected to respond differently each year to the variability we observed. And differences would be exaggerated on the course-textured, xeric soils present. We believe that irregular weather combined with highly variable and stressful soil conditions combined to mask progressive changes in production that might otherwise have been noted.

Annual regrowth in the 12-inch treatment did suggest how this segment of production might be related to weather patterns, although no significant relationship was identified. Annual production was loosely correlated to precipitation during the wettest part of the season, January to March; production was lower in this period when precipitation was high. We believe that overcast conditions at this time may have had an inhibiting effect on photosynthesis and growth.

In the two clipped treatments, the difference in biomass above clipped height is of interest. We believe this is an effect of clipping when starch reserves were low, and the way in which limited reserves were used following the initial clipping in 1981. In the 6inch treatment, growth measured in winter 1982-1983 resulted from the division of available energy between the maintenance of existing plant structure and production of new growth. However, in the 12-inch treatment, more energy was used to maintain more existing plant structure $(80 \%$ more). This distribution of energy resulted in less photosynthetically active growth in the 12-inch treatment, and following the initial clipping, fewer carbohydrates were produced and stored during recovery. Subsequent annual clippings of limited new growth in the 12-inch treatment maintained the differential, but clipping was not severe enough to affect survival in either treatment.

An alternative explanation for the growth differential in the two clipping treatments may be related to observations made by researchers examining the effects of pruning on trees commonly used in cultured environments. When currently growing shoots of mature trees are pruned $50 \%$ or more in early summer (end of June), photosynthesis and carbohydrate production are stimulated (Bory et al. 1995). This suggests that the most severe clipping in our study may have stimulated a more vigorous response, which resulted in the production differential recorded.

\section{Importance of fuel moisture}

Fuel moisture has more influence on ignition potential than other fuelbed characteristics, and it is considered the greatest influence on flammability (Green 1981). Clipping as applied in our study both reduced fuel volume and encouraged new growth high in moisture, nearly half again as great as measured in other segments at the time of clipping. New growth is in the size class (twigs up to 1/8-inch in diameter with attached leaves) used for measuring live fuel moisture, an important predictor of fire behavior; as live fuel moisture rises above about $75 \%$, brushfields become difficult to burn using prescribed fire (Green 1981).

Live fuel moisture is variable among species and it is affected by growing conditions, but it is most variable over the growing season. According to Green, live fuel moisture is highest in spring when it is about $150 \%$ in new growth of most chaparral brush species and less than half this in the old growth (stems 1/2-inch or more in diameter). Minimum live fuel moisture occurs in the late summer or fall when old growth declines to $50 \%$ or less, while new growth may be $5 \%$ to $10 \%$ above this.

A high proportion of new growth is desirable to help reduce fire hazard. According to Green, brush stands with less than $20 \%$ dead material seldom burn satisfactorily when intentionally burned under prescribed conditions to control fuel volume. Clipping (mowing) of chamise chaparral, perhaps as infrequently as once every 15 to 20 years, timed to coincide with the period when shrubs are physiologically weak, will help to maintain growth that is less flammable than mature brush and to retard the accumulation of dead brush that helps carry fire. In addition, clipping only once will permit recovery of the canopy, reduced $60 \%$ to $70 \%$ in our study, and this helps protect the soil surface and reduce erosion.

\section{Cutting considerations and costs}

There appears to be no important advantage in clipping or mowing more closely to the soil surface than 12 inches; cutting larger stems below 12 inches requires more energy and the canopy is further reduced. And below 12 inches, there is a greater risk of hitting obstructions when using mechanical equipment.

A variety of equipment exists for mowing brush. This ranges from tractor-towed and powered rotary mowers of various capacities to equipment specifically designed for cutting 
and chopping logging slash and brush to reduce fire hazards. Rates of production and cost vary based on several considerations, including volume and terrain. But generally, they will be greater and cheaper, respectively, than cutting and piling by hand. The estimated commercial costs using excavator-mounted mastication equipment are $\$ 400$ to $\$ 700$ per acre (Jennifer Boyd, Eldorado Nat'l Forest, personal communication 1998; Yuba Watershed and Fire Safe Council 1998). The cost incurred by the Eldorado National Forest for treating mature manzanita (Arctostaphylos viscida) 6 to 10 feet in height was $\$ 280$ per acre using a brush masticator owned by the Forest (Jennifer Boyd, pers. comm. 1998). Depending on brush density, a hand crew of 16 can clear 1 to $11 / 2$ acres per day at estimated 1998 costs of $\$ 600$ to $\$ 2,500$ per acre (Riley et al. 1980; Yuba Watershed and Fire Safe Council 1998). However, hand crews are needed where terrain and obstructions limit the use of large equipment.

Biomass piled by hand crews must be burned or hauled away, an added expense, unless it will be collected for some use such as energy production, which currently is not attractive from an economic perspective. When mowed or cut and chopped mechanically, brush residues are scattered over the treated area. They are usually divided finely enough to present a much reduced fire hazard compared to standing brush, and the residues act as a mulch to provide soil protection and reduce erosion potential. Chopped and scattered chaparral presents a less porous fuel bed, and it burns with less intensity than untreated brush (Franklin 1996).

As a comparison with other treatment methods, prescribed burning, an often problematic approach to fuel management, is estimated to cost $\$ 75$ to $\$ 200$ per acre (Yuba Watershed and Fire Safe Council 1998). It is useful as a tool for maintenance where fuels have been previously treated. Generally, costs per acre go down as the size of the area treated goes up. However, in addition to the problems noted earlier, personnel trained in the use of fire as a management tool are needed and re- strictions imposed by air-quality regulations must be met.

Finally, the use of herbicides, where environmental considerations permit, can be effective for controlling regrowth. Sprays of foliar-active materials directed by hand can selectively control vegetative growth. Such use is estimated to cost $\$ 150$ to $\$ 300$ per acre (Yuba Watershed and Fire Safe Council 1998).

\section{Clipping: a valuable technique}

Differences in production between clipped and unclipped chamise chaparral in our study were great enough to suggest the value of clipping (mowing) as a fuel management technique. Initially, it reduces standing biomass including the accumulation of dead material that is a major fire hazard. Cutting delays the accumulation of biomass, particularly if timed to coincide with the period in spring when shrubs are physiologically "weak." And the new growth that is stimulated by the process is high in moisture, a major factor acting to reduce flammability.

Our experience suggests that cutting height is not critical, and practical heights may be dictated by obstructions. In addition, the need to prevent accelerated erosion suggests maintaining as much canopy cover as possible. However, the effects of canopy reduction are modified by the scattering of residues when brush is mechanically treated.

Techniques for brush biomass reduction include hand crews and equipment adapted or designed for the purpose. The former usually represent a higher cost, but physical and environmental considerations may dictate their use.

T.E. Adams is Extension Wildlands Specialist Emeritus and P.B. Sands is former Staff Research Associate (retired), respectively, Department of Agronomy and Range Science, UC Davis.

Partial support for this research was provided by the UC Hopland Research and Extension Center (HREC I.D. 50, Grant No. CEFS 0039).

Special thanks for technical information are extended to Professor Emeritus Richard Harris, Department of Environ- mental Horticulture, UC Davis; Farm Advisor Glenn Nader, Sutter-Yuba Counties; and Jennifer Boyd, Fuels Specialist, Georgetown Ranger District, Eldorado National Forest.

\section{References}

Adams TE, Graves WL. 1983. Clipping chaparral as a brush-management technique. Cal Ag 37(3,4):12-4.

Biswell HH. 1974. Effects of fire on chaparral. In: Kozlowski TT, Ahlgren CE (eds.). Fire and Ecosystems. New York: Academic Press. p 321-64.

Bory G, Herbert G, Macle N, ClairMaczulatys D. 1995. Physiological consequences of architectural pruning on trees. In: The tree in its various states. Proc. 2nd European Congress in Arboriculture. Institut pour le Developpement Forestier, Paris, France. p 111-9.

California Resources Agency. 1981. Recommendations on reducing the risk of wildland fires and flooding in California. Report of the Governor's Task Force on Chaparral Fire and Flood Risk Management. Sacramento, $\mathrm{CA}$ : Department of Forestry and Fire Protection. 46+viii p.

Franklin S. 1996. Fuel management. In: Slaughter R (ed.). California's I-Zone-Urban/ Wildland Fire Prevention \& Mitigation. Sacramento, CA: CFESTES bookstore, 7171 Bowling Dr. p 186-93.

Green LR. 1981. Burning by prescription in chaparral. USDA, Forest Service Gen Tech Rpt PSW-51. Berkeley, CA: Pacific Southwest Forest and Range Exp Sta. $36 p$.

Greenlee J, Sapsis D. 1996. Prefire effectiveness in fire management: A summary and review of state-of-knowledge. Wildland Fire Management Series, Vol. 2. Fairfield, WA: International Assoc. of Wildland Fire. $78 \mathrm{p}$.

Hanes TL. 1977. California chaparral. In: Barbour MG, Major J (eds.). Terrestrial Vegetation of California. New York: John Wiley \& Sons. p 417-69.

Jones MB, Laude HM. 1960. Relationships between sprouting in chamise and the physiological condition of the plant. J Range Manage. 13:210-4.

Laude HM, Jones MB, Moon WE. 1961. Annual variability in indicators of sprouting potential in chamise. J Range Manage. 14:323-6.

Lemp C (ed.). 1998. How Can We Live With Wildland Fire? Davis, CA: UC Dept. of Human and Community Development. $41 \mathrm{p}$. Parfit M. 1996. The essential element of fire. Natl Geographic 190(3):117-39.

Riley JG, Moini S, Miles JA. 1980. An engineering study of the harvesting and densification of chaparral for fuel. Davis, CA: UC Dept of Agric Engineering. 94 .

Sampson AW, Jespersen BS. 1963. California range brushlands and browse plants. Publ 4010. Oakland, CA: UC DANR Communications Services, 6701 San Pablo Ave. $162 p$.

Yuba Watershed and Fire Safe Council. 1998. Yuba Watershed Protection/Restoration Project Application. Safe, Clean, Reliable Water Supply Act (Proposition 204); Delta Tributary Watershed Program. State Water Resources Control Board, Sacramento, CA. 